\title{
Screening of Immunocompetent Coelomic Cells in Earthworms
}

\author{
Shweta Yadav ${ }^{1}$
}

\author{
${ }^{1}$ School of Biological Sciences Dr H S Gour Central University, Sagar-470003, MP, India
}

\begin{abstract}
This study describes digital diagnostics density of different coelomic cells in various species of earthworms. Immunocompetent coelomic cells, of different species of earthworms (Eisenia fetida, Eudrilus eugeniae, Eudichogaster prashadi and Perionyx sansibaricus) were isolated and subcultured with exposure of modified cold shock treatment. Study shows that concurrent density of amoebocyte and eleocyte of various species of earthworms can be maintained efficiently for in-vitro studies. The number of coelomocytes per gram of body weight was recorded highest $\left(5.0 \pm 0.8 \times 10^{6} / \mathrm{g}\right)$ in E.fetida and lowest $\left(2.8 \pm 0.7 \times 10^{6} / \mathrm{g}\right)$ in P.sansibaricus. A high percentage of autofluroscence was recorded in eleocyte of Eisenia fetida followed by Perionyx sansibaricus. Aggregates of pigmented granules and brown bodies were recorded almost in all granular amoebocytes and were significantly high in E. prashadi. Study may serve as useful aid in further immuno-cytochemical bioremediation studies and to decipher mechanism of uptake of by coelomic cells of earthworms.
\end{abstract}

Keywords: Coelomocytes, immunocompetent cells, eleocytes, imunocytochemiccal defence in earthworms, coelomic cells of earthworms.

\subsection{Introduction}

Annelids are supposed to be the earliest animals in phylogenetic tree in which both cellular and humoral immune responses are developed. Their body (coelomic) fluid consists various types of immunocompetent cells, the coelomocytes, which take part in various physiological processes including wound healing, blood coagulation, regeneration and other immune responses. These cells may expel out under stressful conditions through inter-segmental dorsal pores with increased intra-coelomic pressure. Various studies (Hosteller and Cooper, 1972; Engelmann et al., 2005) considered them as analogous to leukocyte as they are capable of phagocytosis and perform as function of macrophages. They also have natural killer cell feature, mediate lytic reactions against several targets and also secrete antimicrobial peptides (PorchetHennere et al., 1992; Cooper et al., 1995; Cooper, 2002; Cossarizza et al., 1996; Koros et al., 2002; Madhusudan et al., 2009). Usually earthworm Eisenia fetida was chosen as model organism for the immunological studies/ bio-remediating agent (Hamed et al., 2002; Somogyi, 2012) as they lack adaptive immunity (Fischer and Harvath, 1977) and also display active immune responses (Dhainaut and Scaps, 2011).

A uniform classification of coelomocyte of different species of earthworm is little difficult (Adomowicz and Wojtaszek, 2001) as they exists in various functional states and stages of maturation. Broadly on the basis of morphology, Cooper and Stein (1981) described two type of coelomocytes namely, amoebocytes (hyaline and granular) and eleocyte. Amoebocytes move by pseudopodia devour foreign material and are rich in lysosome. While elecocytes are rich in glycogen particles, lipid droplets and characterised by the presence of distinct yellow granules, chloragosomes. The origin and relationship of coelomocytes are not yet completely known. It was assumed that amoebocyte derived from mesenchymal lining of coelom, whereas, eleocytes originate by detachment of chloragogen cells covering intestinal tract (Affar et al., 1998; Hamed et al., 2002). Chlorogogenic cells are responsible for maintaining constant $\mathrm{pH}$ and ionic balance of both, coelomic fluid and haemolymph (Prento, 1979; Affar et al., 1998). Cooper and Stein (1981) suggested similar origin of hyaline and granular amoebocyte. However, no unambiguous relation was recorded between them. Amoebocyte participate in the transport and storage of nutritive substances (Valembois and Cazaux, 1970), wound healing (Byzowa, 1974), cellular defence reactions (Cooper, 1996), phagocytosis (Stein and Cooper, 1981; Bilej et al., 1990; Dales and Kalac, 1992; Ranzelli-Cain and Kaloustein, 1995; Cossarizza et al., 1996), encapsulation and modulation (Valembois et al., 1994). While, eleocytes play an important role in

This article is published under the terms of the Creative Commons Attribution License 4.0

Author(s) retain the copyright of this article. Publication rights with Alkhaer Publications.

Published at: http://www.ijsciences.com/pub/issue/2016-04/

DOI: 10.18483/ijSci.999; Online ISSN: 2305-3925; Print ISSN: 2410-4477 
immune responses producing bactericidal substances (Valembois et al., 1982; Ville et al., 1995; Milochau et al., 1997) and also participates in reaction of encapsulation and formation of brown bodies (Cooper and Stein, 1981). The number and composition of the coelomocyte depends on exogenous (environmental) as well as endogenous (biotic, life cycle) factors. The interest to study coelomocytes of earthworms as immunocompetent cell is increasing worldwide. Not much work has been carried out to categorize coelomocyte in different species of earthworms. Therefore, the present study was undertaken to perform rapid screening of different coelomocytes, their isolation and sub-culturing of different species of earthworms to investigate their immunocytochemical efficiency in soil system.

\subsection{Materials and Methods}

\subsection{Collection of earthworms}

Four species of earthworms viz., Eudichogaster prashadi (family Octochaetidae), Perionyx sansibaricus (family Megascolecidae), Eisenia fetida (family Lumbricidae) and Eudrilus eugeniae (family Eudrilidae) were collected by digging and hand sorting method from botanical garden, agriculture land and reserved forest area of Sagar MP, India during August - September, 2014. For identification, collected specimens were preserved in ethyl alcohol for molecular characterization, and also fixed in $4 \%$ formalin for morpho-anatomical study. Coelomic cells were extracted from live earthworms and subcultured in $\mathrm{CO}_{2}$ incubator.

\subsection{Characterization of earthworms}

Collected earthworms were identified with the help of available literature (Stephenson, 1923; Gates, 1972; Julka,1988), later re-confirmed with amplified 683 bp cytochrome oxidase coi-I gene. The universal primers, LCO1490

$(5-$ GGTCAACAAATCATAAAGATATTGG-3') and $\mathrm{HCO} 2198$

TAAACTTCAGGGTGACCAAAAAATCA-3')

(Folmer et al., 1994) were used to amplify coi-I gene sequences. Master mix used for PCR reactions contained $1 \mathrm{U}$ Taq polymerase (JonakiTaq, CCMB, Hyderabad, India), $1.5 \mathrm{mM} \mathrm{MgCl}_{2}, 0.2 \mathrm{mM}$ of each primer, $0.125 \mathrm{mM}$ of each deoxynucleotide. Thermal cycling was done in the ABI thermocycler with following conditions of PCR; $4 \mathrm{~min}$ initial denaturation at $94^{\circ} \mathrm{C}, 33$ cycles of 1 min denaturation at $94^{\circ} \mathrm{C}, 1 \mathrm{~min}$ annealing at $45^{\circ} \mathrm{C}, 1 \mathrm{~min}$ elongation at $72^{\circ} \mathrm{C}$, and a final elongation at $72^{\circ} \mathrm{C}$ for $10 \mathrm{~min}$ followed by $4^{\circ} \mathrm{C}$ for $10 \mathrm{~min}$. The PCR products were visualized on $1.0 \%$ agarose gels with $1 \mathrm{X}$ TAE buffer and $0.5 \mu \mathrm{g} / \mathrm{mL}$ EtBr. The PCR products of the expected size were purified using the QIAquick Gel Purification Kit (QIAGEN GmbH, Hilden, Germany) following the manufacturers' protocols. Purified PCR products were sequenced using BigDye
Terminator Cycle Sequencing Kit (Applied Biosystems, Foster City, California) on an ABI3500 with LCO 1490 - HCO2198 primers (Xcelris Genomics Pvt. Ltd., Ahmedabad, India). The electropherograms were processed and analyzed with Bio-edit

(http://www.mbio.ncsu.edu/bioedit/bioedit.html) and phylogenetic analyses was conducted using MEGA v6 (Tamura et al., 2013).

\subsection{Isolation of Coelomocytes}

Collected worms were thoroughly washed in running tap water before rinsing in distilled water and were not subjected to any control condition. Worms were placed on wet cotton to ensure complete defecation in order to avoid contamination during harvesting of coelomocytes. After 2-3 hrs, worms were wiped with cotton wool soaked with $70 \%$ ethyl alcohol to avoid any further contamination. The surface cleaned worms were placed alternately in sterile petridish containing cold extrusion buffer $(\mathrm{NaCl} 71.2 \mathrm{mM}$; Ethanol 5\%; Guaicol-glycerol-ether 50.4mM; EGTA $5 \mathrm{mM}, \mathrm{pH} 7.3$ ) and distilled water at interval of one minute for 8-10 times. Coelomic fluid extruded out through dorsal pores due to external stress condition. After collection of coelomic fluid in cold extrusion buffer, worms were released in soil.

\subsection{Culturing of Coelomocytes}

The excreted coelomic fluid was pipette into tubes filled with LBSS solution $(\mathrm{NaCl} 71.5 \mathrm{mM} ; \mathrm{KCl}$ 4.8mM; $\mathrm{MgSo}_{4} .7 \mathrm{H}_{2} \mathrm{O} 1.1 \mathrm{mM} ; \mathrm{KH}_{2} \mathrm{PO}_{4} 0.4 \mathrm{mM}$, pH 7.3) and centrifuged at $4{ }^{\circ} \mathrm{C}$ for $5 \mathrm{~min}$. Loose pellets of coelomocytes were washed 2-3 times with cold LBSS solution. Cell count was maintained $10^{7} / \mathrm{ml}$ with trypan blue exclusion. The isolated coelomocytes were loaded in petridish with DMEM supplemented with $10 \%$ FBS and incubated for 3 days in $\mathrm{CO}_{2}$ incubator.

\subsection{Cell Viability}

Viability of cells was recorded at the time of isolation and after incubation for three days using haemocytometer and was examined in phase contrast/fluorescence microscope.

\subsection{Statistical Analysis of Data}

Three replicates were considered for statistical analysis. Student's t-test was applied to observe level of significance of cell viability.

\subsection{Results and Discussion}

3.1 Details of earthwormsspp.

Adverting shortly to the presentation of data, all targeted earthworms species collected and identified from the study area are arranged family wise. Each entry gives the information in sequence; scientific name of earthworm species, locality with collection number in parenthesis, date of collection, examined morpho-anatomical characters and sample no. 
examined for molecular characterization.

\author{
3.1.1 Family: Lumbricidae \\ Eisenia fetida (Savigny) \\ Locality and Collection (nos): Patheria village \\ (EW-34; EW-67) Sagar MP, India. \\ Date of collection: 06.09.2014.
}

Characters Examined: Fig 1. Length 70-100 mm; body segment 90-110. Colour reddish brown with distinct stripped appearance of alternating red in equatorial region and yellowish colour that include the inter-segmental furrows. Prostomium epilobic. First dorsal pore 4/5. Setae lumbricine, closely paired. Clitellum from segment xxvi to xxxii; tubercula pubertatis on segment xxviii-xxx. Male pores on segment xv. Spermathecal pores two pairs on inter-segmental furrows $9 / 10$ and $10 / 11$, located dorsally, slightly lateral to mid-dorsal line.

Sample no. examined for molecular characterization: EW34-A-6 (Fig 9).

\subsubsection{Family: Octochaetidae}

Eudichogaster prashadi Stephenson

Locality and Collection (nos): Khaboni Nala (EW54); Gopalpur village (EW-55); Patheria village (EW-58); Khajuria village (EW-97) Sagar MP, India. Date of collection: 04.09.2014.

Characters Examined: Fig 4. Length 90-110 mm; body segments 120-170. Prostomium prolobic. First dorsal pore 12/13. Setae lumbricine. Clitellum covering xiii-xvi. Male genital field tumescent on xvii-xix, with deep slit like depression on xviii and deep longitudinal depression on xviiand xix. Male pores minute, in seminal grooves on the setal arc of $\mathrm{x} v i i i$, at $a b$; prostatic pores minute, at the ends of seminal grooves, on xvii and xix, at $a b$; seminal grooves biconcave, wide and shallow. Female pores single and median, presetal on xiv. Spermathecal pores on setal arcs of vii and ix at $a b$. Genital markings 1-13small circular translucent, irregularly distributed or in transverse rows; unpaired median at $a a$, presetal in $i x, x, x i$ and $x x i$ and in some posterior segments, postsetal on $x i v, x v, x v i$; paired, extending from $a$ or $b$ into $b c$, postsetal on $x v i$, and presetal on $x x$. Oesophagus with 2 gizzards in v-vi and two pairs of discrete extramural calciferous glands in xi-xii; supra-intestinal glands 7-9 pairs in lxxvi-lxxxix (absent in few specimens). Typhlosole simple, lamelliform. Seminal vesicles in $i x$ and $x i i$. Spermathecae flat disc like, multiloculate. Copulatory setae ornamented with several longitudinal rows of excavations.

Sample no. examined for molecular characterization: EW54-A-102; EW55-A-104; EW58-A-110; EW58A-111(Fig 9).

\subsubsection{Family: Megascolecidae}

Perionyx sansibaricus Michaelsen

Locality and Collection (nos): Patheria village (EW48); Dr H.S. Gour University campus (EW-61,EW-
64); Naura Dehi Reserve Forest (EW-63); Semra village, Rehli (EW-90); Juna village, Rehli (EW-91) Sagar MP, India.

Date of collection: 08.09.2014.

Characters Examined: Fig 2. Length 60-90 mm; body segments 110-165. Colour purple dorsally, pale ventrally. Prostomium epilobic. First dorsal pore in any furrows 3/4/5/6. Setae many per segments. Clitellum annular from segment xiii-xvii. Male pore on segment xviii, close together in a median depressed area. Female pore single median, presetal on segment xiv. Spermathecal pores 3 pairs on $6 / 7 / 8 / 9$ close to mid ventral line. Nephridiopores at two levels regularly alternating between dorsolateral and ventrolateral positions on each side. Holonephric, Nephridia stomate with preseptal funnel. Penial setae absent.

Sample no. examined for molecular characterization: EW48-A-92(Fig 9).

\subsubsection{Family: Eudrilidae}

Eudrilus eugeniae (Kinberg)

Locality and Collection (nos): Patheria village (EW-58; EW-71) Sagar MP, India.

Dates of collection: 14.09.2014.

Characters Examined: Fig 3. Length 110-190 mm; body segments 200-210. Colour reddish to purple. Prostomium epilobic. Dorsal pores absent. Setae lumbricine. Clitellum on segments xiv-xviii. Male pores minute, paired at the tip of penes, retractable into copulatory chambers, apertures of copulatory chambers large transverse slits on segment 17, just in front of inter-segmental furrow 17/18. Female pores paired, large transverse slits, close to sides of the body, on segment xiv. Y-shaped gland present which opens though own porophore into copulatory chamber.

Sample no examined for molecular characterization: EW71-A-25(Fig 9).

\subsection{Coelomocytes in different species of earthworms} Different coelomocytes of Eisenia fetida; Eudichogaster prashadi; Perionyx sansibaricus and Eudrilus eugeniae were observed and illustrated in Fig 5 to 8. A high percentage of autofluroscence was recorded in eleocyte of $E$. fetida (Fig $5 \mathrm{~d}$ ) followed by P. sansibaricus (Fig 7d). Aggregates of pigmented granules, brown bodies were recorded almost in all granular amoebocyte and significantly high in $E$. prashadi (Fig 6a). Precise reason of their increase in particular species is unknown, but it may indicate their efficiency of phagocytosis and encapsulation activity of invading bacteria/particulate waste. A remarkable divergence in fluorescence granules in eleocyte was detected in different earthworm species and a very high density was recorded in E. fetida. The studies on fluorescence activity of eleocyte of earthworms are very limited, to name some Albani et al., 2003; Cholewa et al., 2006; Plytycz et al., 2006. Valembois et al. (1994) demonstrated the 
synthesis of lipofuscin and melanin during the formation of brown bodies by coelomocytes of $E$. andrei and these brown aggregates were also recorded significantly high in E. Prashadi (Fig 6a) in present study. This may be resulted from the insolubilization of oxidised organic substrates (last stage of catabolism and segregation of unwanted material in granular amoebocytes as suggested by Cholewa et al., 2006). It can be speculated that free floating amoebocytes may shed from the degraded eleocytes. The observed fluorescence material may be due to flavins (Aubin, 1979), porphyrins (Yang et al., 1987) and/or lipofuscins (Terman and Brunk, 2004; Yang et al., 1987). The flurophores deposited in the eleocytes may be different from those deposited in coelomic fluid containing free wandering coelomocytes. It was observed that hyaline amoebocytes in all species of worms have numerous pseudopodia and are distributed in the cell periphery with short lobopodia (Fig 5b, 6b, 7b, 8b). Adomowicz and Wajtaszek (2001) differentiated these amoebocyte into AI (regularly distributed numerous pseudopodia on the cell periphery and with short lobopodia); and AII (irregularly distributed pseudopodia, often at one pole of cell with long filopodia). These differentiations were not observed in present study. All authors agreed to call them inclusively amoebocyte rather than I and II. As the formation of pseudopodia, the shape of the nucleus and the granular cytoplasm represents the maturity and metabolic activity of amoebocyte.

\subsection{Density of coelomocytes}

The number of coelomocytes per gram of body weight was highest $\left(5.0 \pm 0.8 \times 10^{6} / \mathrm{g}\right)$ in E.fetida and lowest $\left(2.8 \pm 0.7 \times 10^{6} / \mathrm{g}\right)$ in P.sansibaricus (Table 1). While, the body weight of E.fetida was recorded $0.60 \pm 0.04 \mathrm{~g}$ and P.sansibaricus ranges $0.40 \pm 0.02 \mathrm{~g}$. In E.prashadi (body weight, $1.18 \pm 0.16 \mathrm{~g}$ ) total cell count were $4.0 \pm 0.6 \times 10^{6} / \mathrm{g}$; and in E.eugeniae (body weight, $2.10 \pm 0.16 \mathrm{~g}) 3.4 \pm 0.3 \times 10^{6} / \mathrm{g}$. This indicates body weight of worms is not affecting the number of coelomocytes inhabiting the coelomic cavity. There may be species-specific correlation between the percentage of coelomocytes and earthworm species that needs further investigation. The autofluroscent

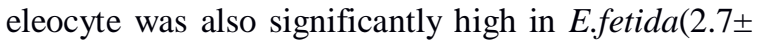
$\left.0.5 \times 10^{6} / \mathrm{g}\right)$ followed by E.eugeniae $\left(2.0 \pm 0.2 \times 10^{6}\right.$ $/ \mathrm{g})$. While, granular amoebocyte was recorded high $\left(2.8 \pm 0.8 \times 10^{6} / \mathrm{g}\right)$ in E.prashadi and in other species varies $1.0-2.8 \pm 0.1 \times 10^{6} / \mathrm{g}$. Differentiation in these cells also not revealed any relation with total cell count and body weight of worms.

A gradual increase in cell density from the time of isolation to subculturing was recorded in all species. After incubation of three days the highest total cell count $\left(8.2 \pm 0.6 \times 10^{6} / \mathrm{g}\right)$ was observed in E.fetida followed by E.prashadi $\left(6.2 \pm 0.6 \times 10^{6} / \mathrm{g}\right)$. Number of autofluroscent eleocytes increased significantly in subculturing, while the subculturing of hyaline amoebocyte were not obtained in optimum count. The culture plate of proliferating cells in present study didn't exhibit any bacterial or fungal contamination, even though, any antibiotic /antifungal agent was not used in the present study. Some protozoan contamination at the stage of isolation was recorded but was subsided with future culturing and subculturing. The modified protocol used in present study revealed that the coelomocytes can be successfully isolated and cultured with the application of cold shock treatment. Also, subculture can be used for further immunocytochemical studies. The percentage of various coelomocytes may be species specific, but seasonal environmental stress may not be ignored. At present, we cannot exclude possibility of variation in number and size of coelomocytes in relation to availability of nutritive compounds as well as their annual cycles. The study can serve as useful aid to decipher the mechanism of uptake and scavenging of pollutants by coelomocytes of different species of earthworms' in-vitro.

\subsection{Acknowledgement}

We acknowledge the financial support of the Department of Biotechnology, Ministry of Science and Technology, Govt. of India, New Delhi, to carry out this study.

\subsection{Competing Interest}

The authors declare that they have no competing interests.

\subsection{Reference}

1) Adomowicz, Anna and Wojtaszek, Jan, 2001. Morphology and phagocytic activity of coelomocytes in Dendrobaena veneta (Lumbricidae). Zoologica Poloniae 46/1-4:91-104.

2) Affar,E.B., Dufour,M., Poirier,G.G. and Nadeau,D.,1998. Isolation, purification and partial characterization of chloragocytes from the earthworm species Lumbricus terrestris. Mol. Cell. Biochem. 185: 123-133.

3) Albani,J.R., Demuynck, S., Grumiaux,F. and Lepretere,A., 2003. Fluorescence fingerprints of Eisenia fetida and Eisenia andrei. Photochem.Phtobiol. 78:595-602.

4) Aubin, J.E., 1979.Autofluorescence of viable cultured mammalian cells. J. Histochem. Cytochem. 27: 36-43.

5) Bilej,M.,Vetvicka,V.,Tuckova,L.,Trebichavsky,I., Koukal,M.,I.M.A.,1990. Phagocytosis of synthetic particles in earthworms and effect of antigenic stimulation and opsonisation. Folia. Biol. 36:273.

6) Byzowa,J.B.,1974.The dynamics of some blood indices in earthworm (Oligochaeta,Lumbricidae). Rev. Ecol.Biol.Sol. 11:325-332.

7) Cholewa Justyna, Feeney, P.Graham, Reilly, MichaelO., Sturzenbaum, R., Stephen, Morgan,J. A., Plytyez Barbara,2006. Autofluroscence in eleocytes of some earthworms. Folia Histochemica et Cytobiologica 44(1): 6571.

8) Cooper, E.L., 2002.The earthworm a new model with biomedical applications .In: A new model for analyzing antimicrobial peptides with biochemical applications. Beschin A, Bilej M,Cooper EL(Eds),IOS Press, Ohmsha pp 3-26.

9) Cooper,E.L., 1996. Earthworm immunity. In: Invertebrate Immunology. Rincevich,B. and Muller,W.E.G. (Eds). Springer-Verlag,Berlin-Heidelberg.

10) Cooper,E.L. and Stein,E.A.,1981.Oligochaetes.In: 
Invertebrates Blood cells. Ratcliffe, N.A. andRowley, A.F.(Eds.), Academic Press, London- San Francisco, pp 75140.

11) Cooper,E.L.,Cossarizza,A.,

Suzuki,M.M.,Salvioli, S.,Capri,M., Quaglino,D.,Franceschi, C.,1995. Autogencic but not allogecic earthworm effector coelomocytes kill the mammalian tumor cell target K562.Cellular Immunology 166: 113-122.

12) Cossarizza,A.,Cooper,E.L.,Suzuki,M.M.,Salvioli,S.,Capri,M. ,Quaglino,D.,Franceschi,C.,1996. Earthworm leucocytes that are not phagocytic and cross-react with several human epitopes can kill human tumor cell lines. Exp. Cell Res. 224:174-182.

13) Dales,P. and Kalac,Y., 1992. Phagocytic defence by the earthworm Eisenia fetida against certain pathogenic bacteria. Comp. Biochem. Physiol. 101: 487-490.

14) Dhainaut,A. and Scaps,P.,2011. Immune defence and biological responses induced by toxics in Annelida.Canadian J. of Zoology 79: 223-253.

15) Engelmann,P., Cooper, E.L., Nemeth, P., 2005.Anticipating innate immunity without a toll. Molecular Immunology 42:931-942.

16) Fischer E.andHarvath,I., 1977. In vivo accumulation and discharge of azine,thiazine, and xanthenes dyes and their effects on the Chlorogogen cells of Lumbricidae (Oligochaeta).Acta Biological AcademiaeScientiarumHungaricae 28: 33-47.

17) Folmer, O.,Black, M.,Hoeh, W., Lutz, R.., and Vrijenhoek, R. 1994. DNA primers for

18) amplification of mitochondrial cytochrome c oxidase subunit I from diverse metazoan

19) invertebrates. Mol. Marine Biol.and Biotech. 3(5): 294-299.

20) Gates, G.E., 1972. Burmese earthworms: An introduction to the systematics and biology of MegadrileOligochaeteswith special reference to south-east Asia. The American Philosophical Society Independence Society, Independence Square, Philadelphia.

21) Hamed,S.S., Kauchke, E.,Cooper,E.L., 2002.Cytochemical properties of earthworm coelomocytes enriched by Percoll.In: A new model for analyzing antimicrobial properties with biomedical applications. Beschin, A.,Bilej, M.,Cooper E.L.(Eds.), IOS Press Ohmsha,pp 29-37.

22) Hosteller,R.K. and Cooper,E.,1972.Coelomocytes aseffector in earthworm immunity. Immunol. Chem.12:155-183.

23) Julka,J.M.,1988.Fauna of India: Megadrile Oligochaeta (Earthworms),Zoological Survey of India,Calcutta, India.

24) Koros,A.M., Goodwin,D.G.,Siderits,R.H.,Malavasi,F., 2002.Natural Killer(NK) cell antigens CD56,CD57 and others are expressed on breast and lung tumor cells as well as sea urchin coelomocytes. J. Biological Regulation and Homeostatic Agent 16: 173-175.

25) Madhusudan N.,Preetha Nair,Kale, D.Radha.,2009. Isolation and culturing of earthworm (Eudrilus eugeniae) coelomocytes. Dynamic Soil \&Dynamic plant 2: 11-114.

26) Milochau, A., Lassegues, M., Valembois, P., 1997.Purification, characterization and activities of two haemolytic and antibacterial protein from coelomic fluid of the annelid Eiseniafetidaandrei.Biochem.Biotyphs.Acta. 1337:123-132.

27) Plytycz, B., Homa, J., Koziol, B., Rozanowska, M., Morgan, A. J., 2006. Riboflavin content in autofluroscent earthworm coelomocytes in species-specific. Folia Histochemica et Cytobiologica 44: 275-280.

28) Porchet-Hennere,E.,Dugimont, Fischer, A., 1992. Naturalkiller cells in a lower invertebrate, Nereis diversicolor. European J. Cell Biology 58:99-107.

29) Prento,P., 1979.Metals and phosphate in the chloragosomes of Lumbricus terrestris and their possible physiological significance.Cell Tissue Res. 196:123-134.

30) Ranzelli-Cain,R.and Kaloustein,K.V.,1995.Evidence for the involvement of opioid peptides in phagocytosis conformation, granulation and aggregation of immunocompetent Lumbricus terrestris amoebocytes. Comp. Biochem. Physiol. 111:2015-211.

31) Somogyi,IIdiko, 2012.Coelomocytes of Eisenia fetida: Structure, function, origin. Ph.D. Thesis University of PECS, Hungary.

32) Stein, E. and Cooper, E.L., 1981. The role of opsorins in phagocytosis by coelomocytes of the earthworms, Lumbricus terrestris. Dev. Comp. Immunol. 5 :415-425.

33) Stephenson, J., 1923. The fauna of British India: Oligochaeta Taylor and Francis, Red Lion Court, Fleet Street.

34) Tamura K., Stecher G., Peterson D., Filipsk,I A., Kumar, S., 2013. MEGA6: Molecular Evolutionary Genetics Analysis version 6.0. Molecular Biology and Evolution 30: 27252729.

35) Terman, A. and Brunk,U.T.,2004.Lipfuscin. Int J. Biochem Cell Biol. 36:1400-1404.

36) Valembois,P. andCazaux,M.,1970.Etude autoradiographique du role trophiques des cellules chloragogenes des vers de terre. CR. Soc. Biol.164:1014-1021.

37) Valembois,P.,Roch,P.,Lassegues,M.,Davant,N.,1982.Bacteti ostatic activity of a chlorogogen cell secretion. Pedobiologia 24:191-195.

38) Valembois,P.,Semour, J.,Lassegues,M.,1994.Evidence of lipofuscin and melanin in the brown body of the earthworm Eisenia fetida andrei. Cell Tiss.Res. 277:183-188.

39) Ville,P., Roch,P., Cooper,E., Masson,P., and Narrbonne,J.,1995. PCBs increase modular -related activities (lysosome, antibacterial, hemolysis, proteases) but inhibit macrophage-related functions (phagocytosis, wound healing)in earthworms. J. Invertebr. Pathol. 65: 217-24.

40) Yang,Y.L.,Ye Y.M.,Li, Y.F.,Ma, P.Z.,1987.Characteristic autofluroscence for cancer diagnosis and its origin. Lasers Surg Med. 7: 528-532.

Figures Legend:

Fig 1.Diagonistic characters of E.fetida; a, anterior region; b, tubercula pubertitis; c, male gonopore; d, nephridia; e, spermathecae; f, complete worm.

Fig 2.Diagonistic characters of P. Sansibaricus; a, prostomium ; b female gonopore; c, nephridia; d, stomata nephridia ; e, nephridiopores; f, spermathecal pore ; g, different parts of nephridia; h, nephrostome; i, complete worm .

Fig 3.Diagonistic characters of E.eugeniae; a, Copulatory chamber with penis ; b, female gonopore; c, Y-shaped gland; d, testes with seminal vesicle; e, complete worm

Fig 4.Diagonistic characters of E.prashadi; a, male region showing seminal grooves;

b,genital markings; c, calciferous gland; d, complete worm.

Fig 5.Coelomic cells of Eisenia fetida; a, granular amoebocyte $(40 \mathrm{X})$; b, hyaline amoebocyte $(40 \mathrm{X})$; c, eleocyte $(40 \mathrm{X})$; d, fluorescent eleocyte (100x)

Fig 6 Coelomic cells (40X) of Eudichogaster prashadi; a, granular amoebocyte; b, hyaline amoebocyte; c, fluorescent eleocyte.

Fig 7. Coelomic cells (40X) of Perionyx sansibaricus; a, granular amoebocyte; b, hyaline amoebocyte; c, eleocyte; d, fluorescent eleocyte (100x).

Fig 8. Coelomic cells (40X) of Eudrilus eugeniae; a, granular amoebocyte; b, hyaline amoebocyte; $c$, fluorescent eleocyte.

Fig 9.The evolutionary history was inferred using the NeighborJoining method [1]. GenBank accession description of the sequences from earlier studies was shown in the phylogenetic tree along with bootstrap test (1000 replicates) next to the branches [2]. Sepia aculeata COI gene, cuttlefishes (Mollusca) was used as out group. Bar 5 changes/100 characters. Evolutionary analyses were conducted in MEGA v6 [3]. 


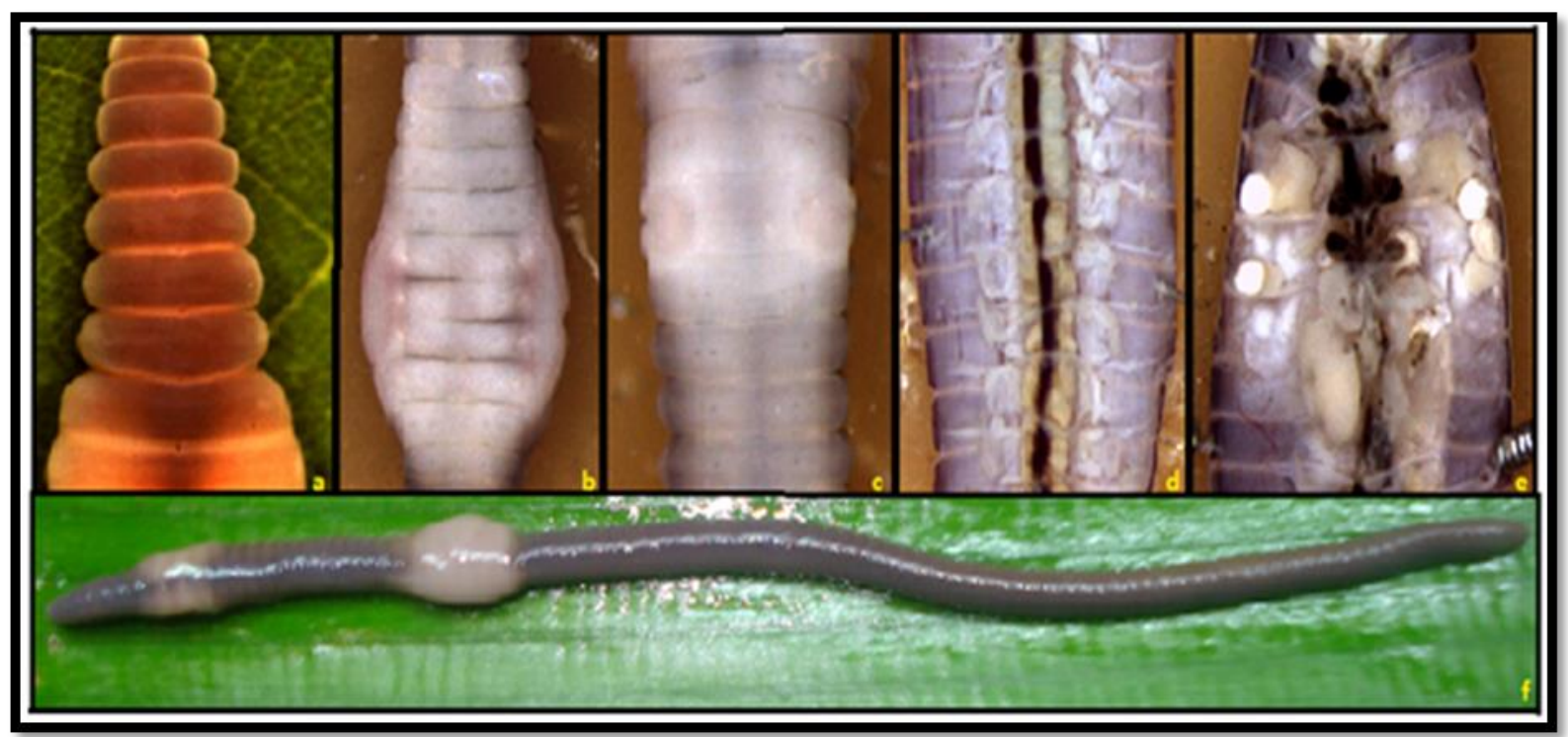

Fig 1.Diagonistic characters of E.fetida; a, anterior region; b, tubercula pubertitis; c, male gonopore; d, nephridia; e, spermathecae; f, complete worm.

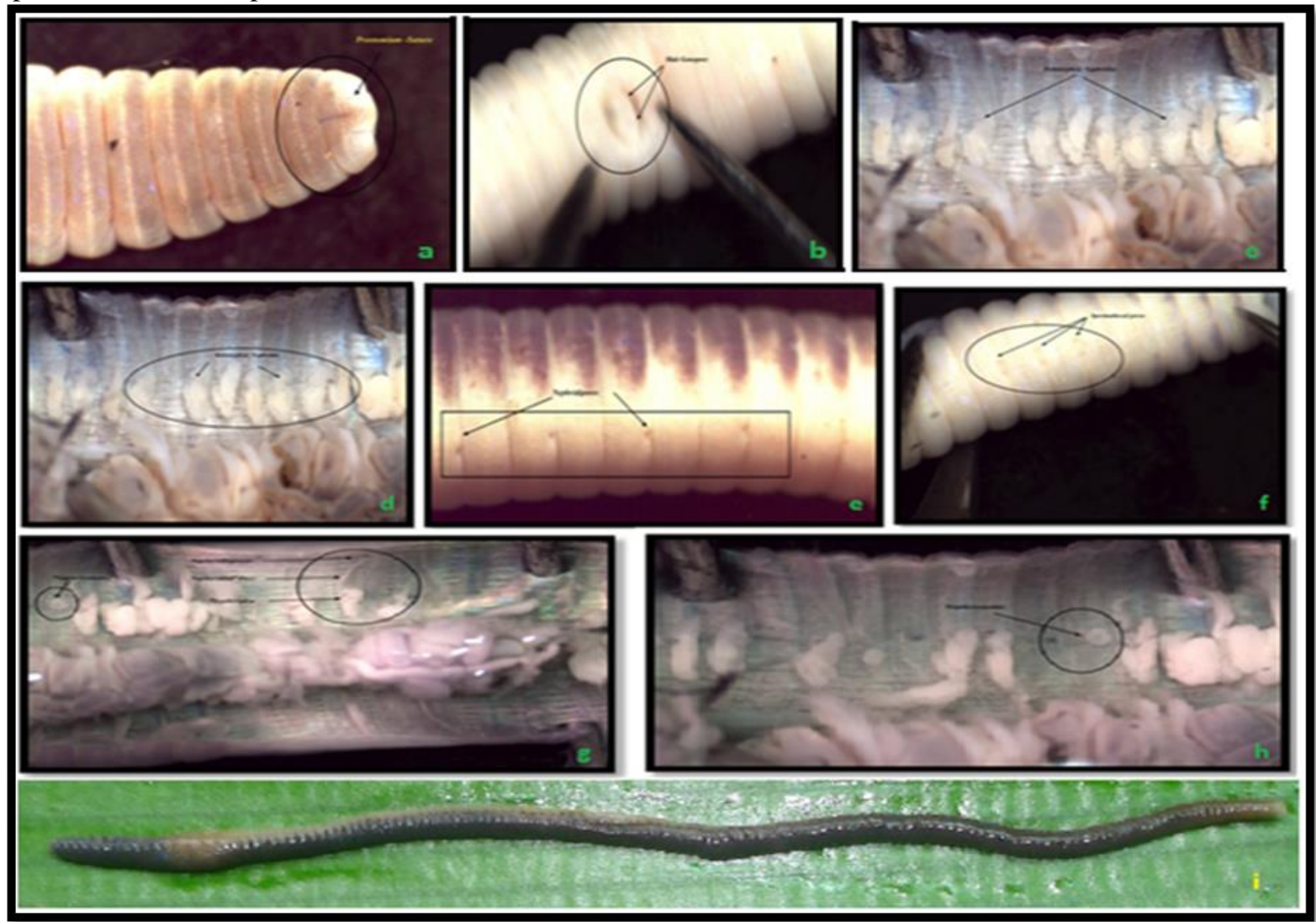

Fig 2.Diagonistic characters of P. Sansibaricus; a, prostomium ; b female gonopore;

c, nephridia; d, stomata nephridia ; e, nephridiopores; f, spermathecal pore ; g,

different parts of nephridia; $h$, nephrostome; i, complete worm 


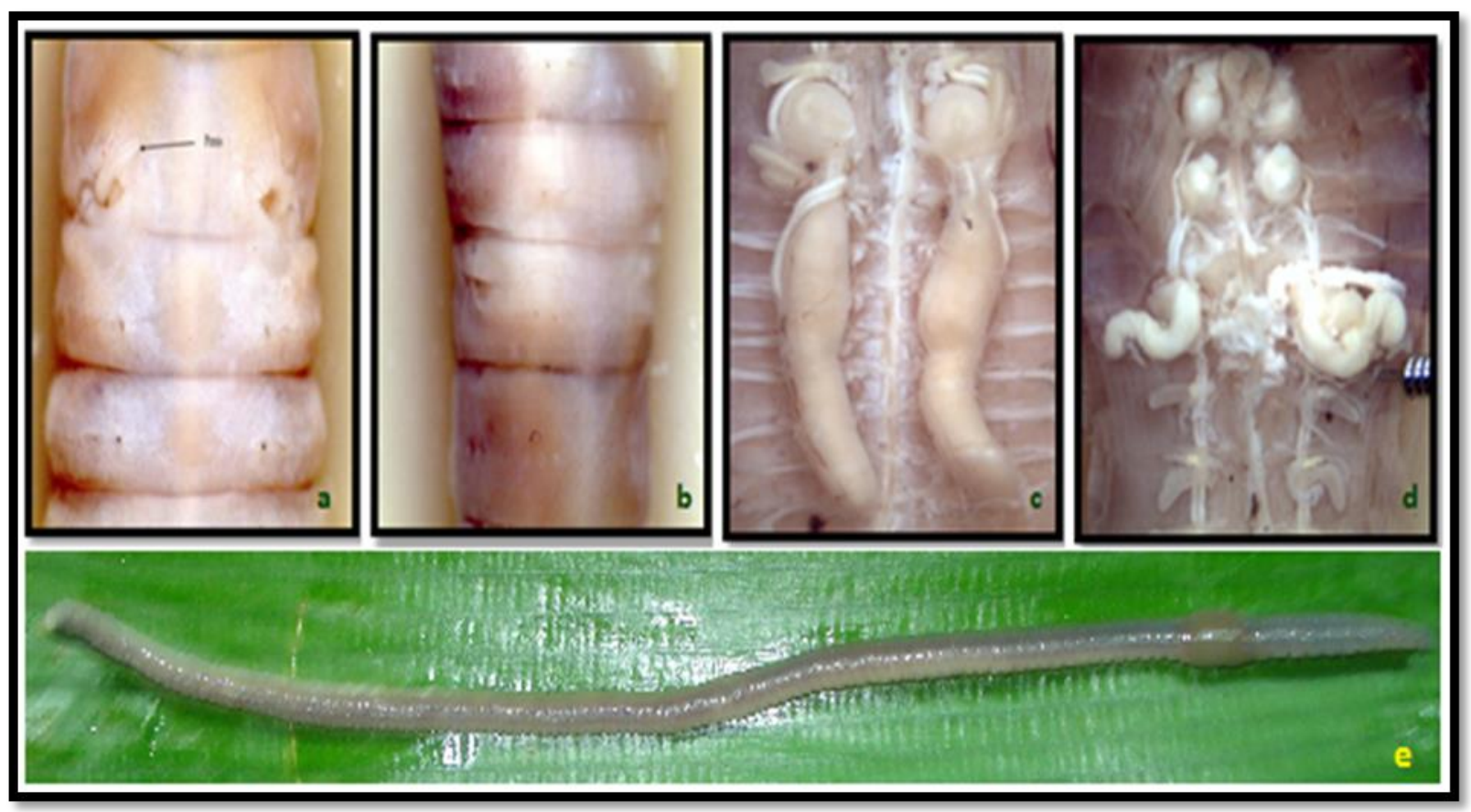

Fig 3.Diagonistic characters of E.eugeniae; a, Copulatory chamber with penis ; b, female gonopore; c, Y-shaped gland; d, testes with seminal vesicle; e, complete worm

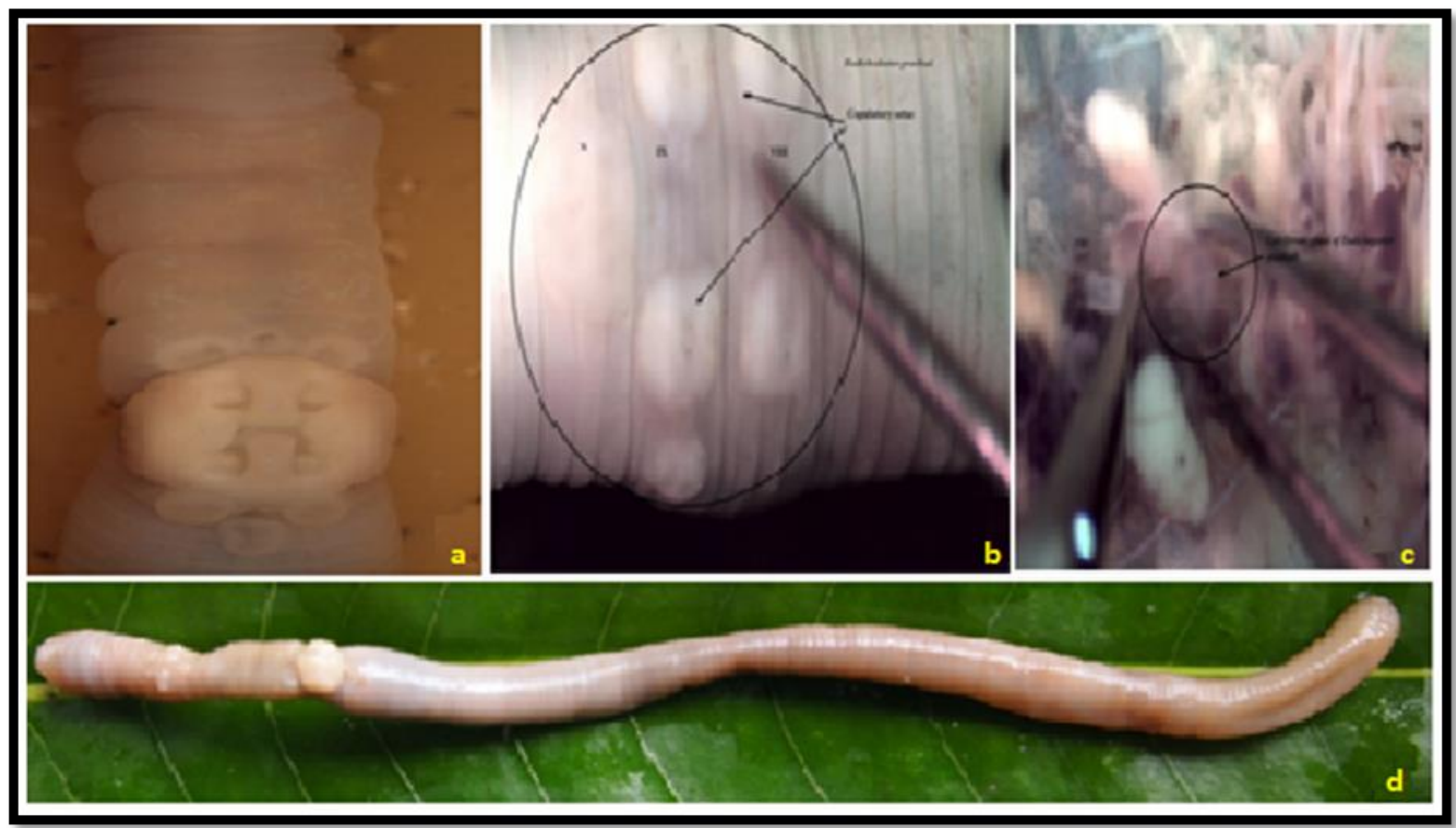

Fig 4.Diagonistic characters of E.prashadi; a, male region showing seminal grooves;

b,genital markings; c, calciferous gland; d, complete worm 


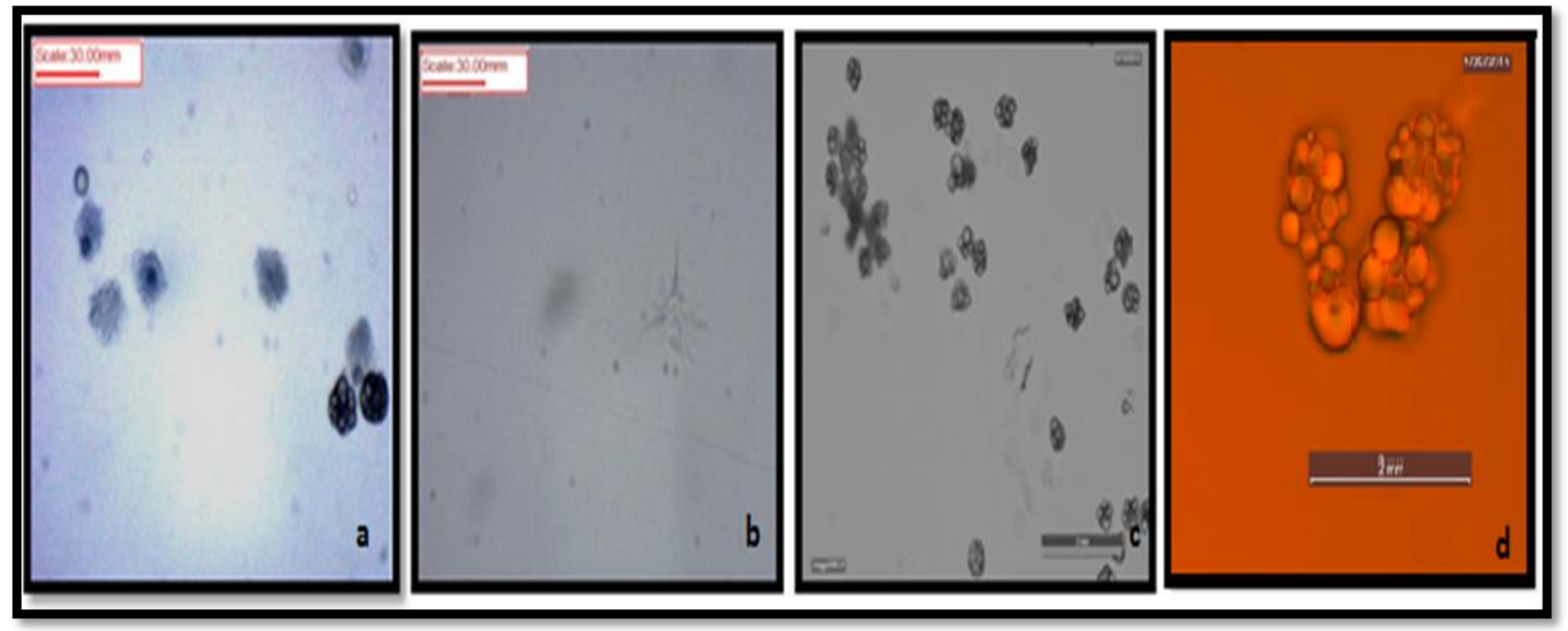

Fig 5.Coelomic cells of Eisenia fetida; a, granular amoebocyte (40X); b, hyaline amoebocyte (40X); c, eleocyte $(40 X) ; d$, fluorescent eleocyte $(100 x)$

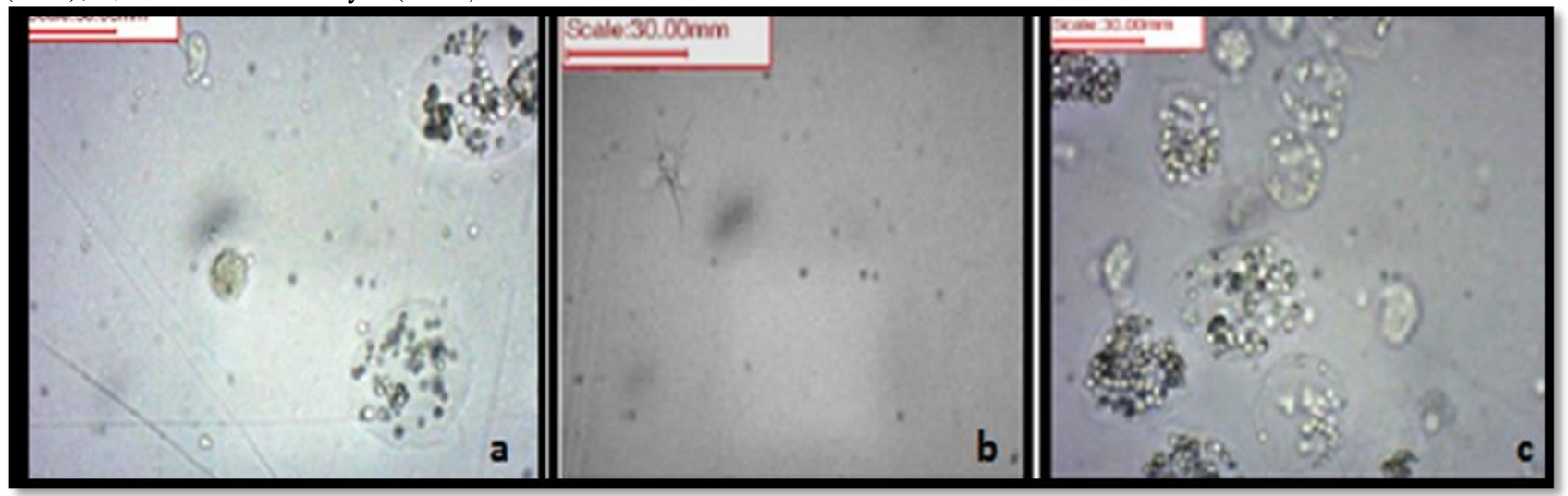

Fig 6 Coelomic cells (40X) of Eudichogaster prashadi ; a, granular amoebocyte; b, hyaline amoebocyte; c, fluorescent eleocyte

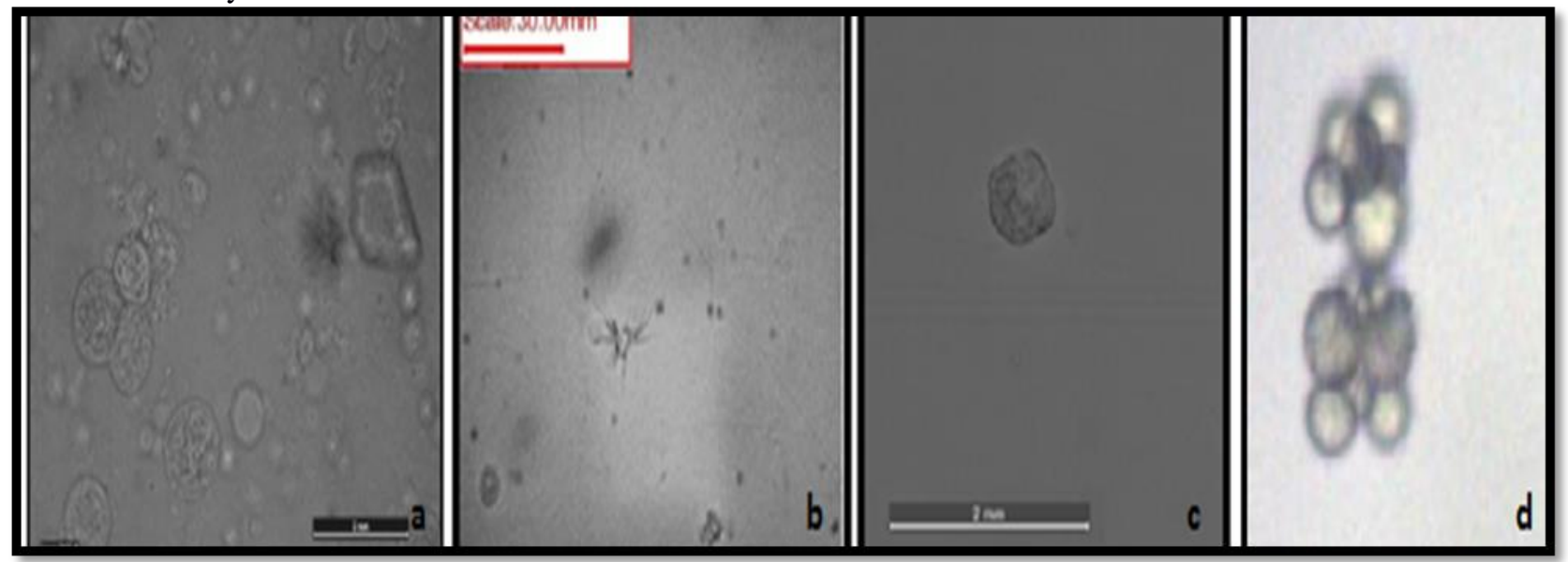

Fig 7. Coelomic cells (40X) of Perionyx sansibaricus; a, granular amoebocyte; b, hyaline amoebocyte; c, eleocyte; d, fluorescent eleocyte (100x) 


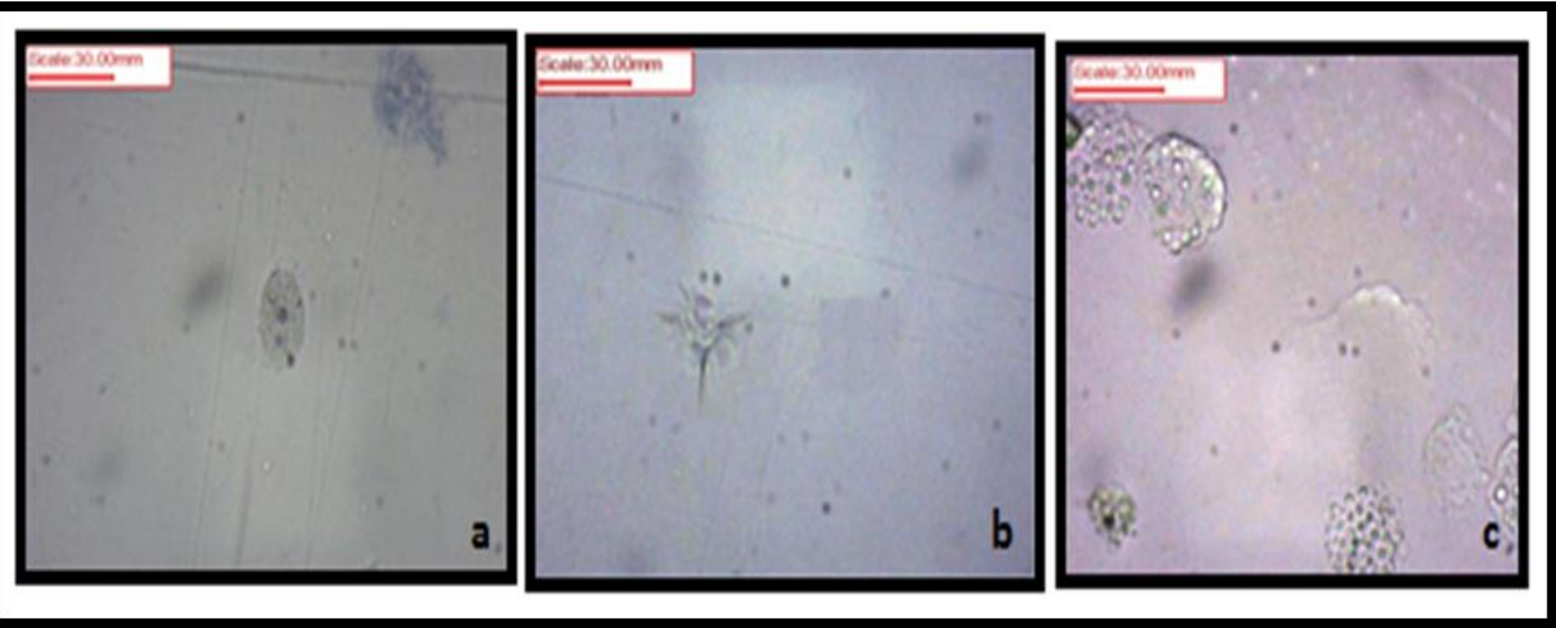

Fig 8. Coelomic cells (40X) of Eudrilus eugeniae; a, granular amoebocyte; b, hyaline amoebocyte; c, fluorescent eleocyte

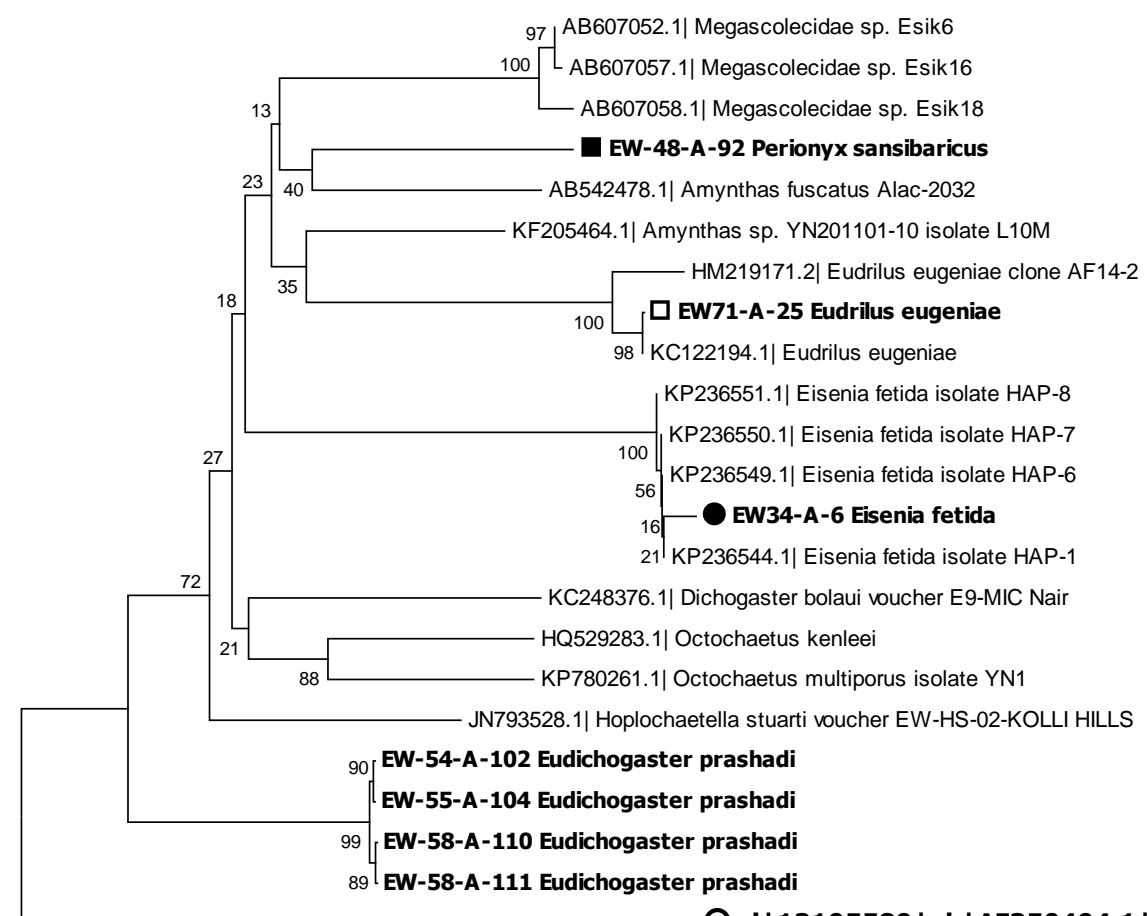

O gi | 13195589 | gb | AF350494.1 | Sepia aculeata

Fig 9.The evolutionary history was inferred using the Neighbor-Joining method [1]. GenBank accession description of the sequences from earlier studies was shown in the phylogenetic tree along with bootstrap test (1000 replicates) next to the branches [2]. Sepia aculeata COI gene, cuttlefishes (Mollusca) was used as out group. Bar 5 changes/100 characters. Evolutionary analyses were conducted in MEGA v6 [3]. 